\title{
ALAT PENGONTROL KADAR pH AIR DAN NUTRISI AB MIX MENGGUNAKAN ARDUINO PADA SISTEM HIDROPONIK SAYUR HIJAU
}

\author{
Tri Atmaja*1 , Abdi Pandu Kusuma ${ }^{2}$ \\ 1,2 Jurusan Sistem Komputer, FTI Universitas Islam Balitar, Universitas Islam Balitar; \\ Jl. Majapahit 2-4 Blitar \\ Telp. (0342)813145 Fax (0342)4557025 \\ e-mail: *1 majaat08@gmail.com, *2 pans.uiblblitar@gmail.com
}

\begin{abstract}
The world of technology today has developed quite rapidly with a lot of manufacture and development of various kinds of equipment that are able to help humans do work that is both control and automatic. One example of technological developments is automatic plant watering, smart home, automatic bird feeder, and many more. This study discusses a tool to control water $\mathrm{pH}$ levels and nutrients using Arduino in a green vegetable hydroponic system. The sensor used is the pH Electrode E201-C BNC sensor as a reader of pH levels in water, the TDS Meter V.1 sensor as a reader of nutrient density levels in water, and an ultrasonic sensor as a reader of water level in the reservoir to determine the volume of water so that it does not will run out. The software used is the Arduino Uno IDE. The way this tool works is that the input from the sensor will be processed by Arduino and the result is in the form of output conditioning, namely the actuator is on or not.
\end{abstract}

Keywords: pH Electrode E201-C BNC, TDS Meter, Arduino

\section{PENDAHULUAN}

\subsection{Latar Belakang}

Di era globalisasi saat ini perkembangan teknologi merupakan salah satu indikator kemajuan suatu negara. Dengan adanya sebuah teknologi, pekerjaan yang dilakukan masyarakat akan menjadi lebih mudah dalam segala bidang. Di negara Indonesia teknologi telah merambah di segala aspek kehidupan. Dalam aspek pertanian, mulai bermunculan teknologi dalam bercocok tanam, misalnya penyiram tanaman otomatis, sistem informasi kondisi tanaman

Menurut sutiyoso (2004), hidroponik berasal dari kata hidro yang berarti air dan ponus yang berarti daya. Dengan demikian, hidroponikadalah sistem bercocok tanam tanpa menggunakan media tanah, akan tetapi sistem ini menggunakan air sebagai media pertumbuhan tanaman.

Nyoman (2016) menjelaskan bahwa Nutrient Film Technique (NFT) adalah teknik hidroponik yang menempatan akar tanaman di pada campuran air dengan nutrisi yang disirkulasikan terus menerus melewati akar tanaman.

Harum Cahyani(2016) menerangkan bahwa Total Dissolved Solids (TDS) merupakan jumlah material atau larutan yang terdapat dalam air. Alat yang dapat digunakan untuk mendeteksi kadar TDS yaitu Total Dissolved Solids Sensor Meters (sensor TDS meter). Sensor TDS meter bekerja dalam satuan Part Per Milions (PPM). Semakin besar nilai PPM maka semakin pekat larutan yang terdapat dalam air tersebut.

Ika Kustanti (2014) mengungkapkan bahwa kadar $\mathrm{pH}$ yang berlebihan dapat mengganggu pertumbuhan tanaman antara lain kerusakan membran akar, selain itu daun maupun buah menjadi berwarna lebih kuning sehingga jika buah dapat tumbuh akan menghasilkan buah yang kurang manis. ph mempunyai angka indikator 1 sampai 14 , dalam sistem hidroponik ph normal berada di angka indikator 7, jika ph meter berada di angka indikator dibawah 7 maka menunjukan air tersebut mempunyai kadar asam, sedangkan jika ph meter berada di angka indikator diatas 7 maka menunjukkan air tersebut mempunyai kadar basa. kegiatan pengontrolan nutrisi dan $\mathrm{pH}$ secara manual membuat petani hidroponik harus menyempatkan waktu dan tenaga agar kadar nutrisi dan ph tetap terjaga sehingga pengontrolan secara manual tidak dapat dilakukan saat petani hidroponik berada di luar kota atau masih dalam kesibukan yang lain sehingga perlu adanya sebuah alat yang dapat mengontrol kebutuhan tanaman hidroponik setiap saat agar kondisi tanaman hidroponik dapat

terjaga disaat pemilik hidroponik berada diluar kota atau mempunyai kesibukan lainnya.

Otomatisasi dapat menjadi solusi dalam pemberian nutrisi dan $\mathrm{pH}$ jika pemilik tidak dapat melakukannya. Proses otomatisasi perlu adanya sebuah mikrokontroller dan beberapa sensor untuk melakukan pengontrollan dan pemberian nutrisi.

Menurut Sulaiman (2012:1), arduino merupakan platform yang terdiri dari software dan hardware. Arduino sama seperti mikrokontroller lainnya, namun terdapat penamaan pin supaya mudah diingat. Fungsi dari arduino yaitu menyimpan dan melaksanakan perintah yang telah dimasukkan oleh pengguna sekaligus melakukan kontrol terhadap perangkat tambahan yang 
terhubung ke arduino. Dalam penelitian ini, arduino tidak dapat melakukan tugasnya tanpa adanya alat tambahan yang berupa sensor untuk mendeteksi adanya nutrisi dan ph dalam air yakni Total Dissolved Solidsuntuk arduino (TDS) dan ph meter untuk arduino.

Berdasarkan latar belakang diatas, peneliti tertarik untuk melakukan penelitian dengan judul "Alat Pengontrol Kadar pH Air dan Nutrisi AB Mix Otomatis Menggunakan Arduino pada Sistem Hidroponik Sayur Hijau” .

Berdasarkan latar belakang yang telah dikemukakan, peneliti dapat merumuskan masalah sebagai berikut :

a. Bagaimana rancang bangun alat pengontrol kadar $\mathrm{pH}$ air dan nutrisi abmix menggunakan arduino pada sistem hidroponik sayur hijau ?

b. Bagaimana pengujian alat pengontrol kadar $\mathrm{pH}$ air dan nutrisi abmix menggunakan arduino pada sistem hidroponik sayur hijau ?

Adapun tujuan dari penelitian yaitu :

a. Mengetahui rancang bangun alat pengontrol kadar $\mathrm{pH}$ air dan nutrisi abmix menggunakan arduino pada sistem hidroponik sayuran hijau

b. Mengetahui hasil pengujianalat pengontrol kadar $\mathrm{pH}$ air dan nutrisi abmix menggunakan arduino pada sistem hidroponik sayuran hijau

\section{METODE}

\subsection{Jenis Penelitian}

Jenis Penelitian yang digunakan yaitu jenis penelitian dan pengembangan atau research and development. Tujuan dari metode jenis ini yaitu menghasilkan dan menguji produk sehingga dapat mencipakan sebuah produk yang berkualitas. Produk yang akan dikembangkan dalam penelitian ini yaitu alat pengontrol kadar ph dan nutrisi otomatis dalam sistem hidroponik dengan menggunakan langkah langkah penelitian model Sugiyono. Sugiyono (2011 : 298) menjelaskan bahwa, penelitian dan pengembangan atau Research and Development ada sepuluh langkah sebagai berikut: (1) Potensi dan masalah, (2) Pengumpulan data, (3) Desain produk, (4) Validasi desain, (5) Revisi desain, (6) Ujicoba produk, (7) Revisi produk, (8) Ujicoba pemakaian, (9) Revisi produk, dan (10) Produksi missal.

\subsection{Prosedur Pengembangan}

Prosedur pengembangan yang dilakukan untuk mengembangkan Alat Pengontrol Kadar $\mathrm{Ph}$ dan Nutrisi Otomatis menggunakan Arduino dalam Sistem Hidroponik yaitu model pengembangan sugiyono. Alur dan penjelasan mengenai model pengembangan sugiyono sebagai berikut :

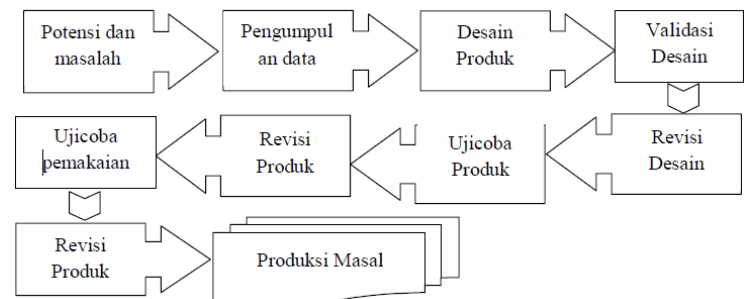

Gambar 2.1. Alur Metode Research and Development(R\&D) menurut Sugiono

(Sumber : Sugiono 2015)

\subsection{Desain Alat}

Alat pengontrol kadar ph dan nutrisi menggunakan arduino sebagai mikrokontroller, sensor ultrasonik untuk mengukur tinggi air pada bak penampungan air hidroponik, sensor ph meter untuk mengukur kadar ph, sensor TDS meter untuk mengukur kadar nutrisi, waterflow swicth sebagai keran otomatis, dan pompa air dc yang digunakan untuk mengalirkan air dari penampungan air utama ke bak penampungan air hidroponik serta untuk mengalirkan air ke tanaman hidroponik. Berikut desain mengenai alat pengontrol kadar ph dan nutrisi.

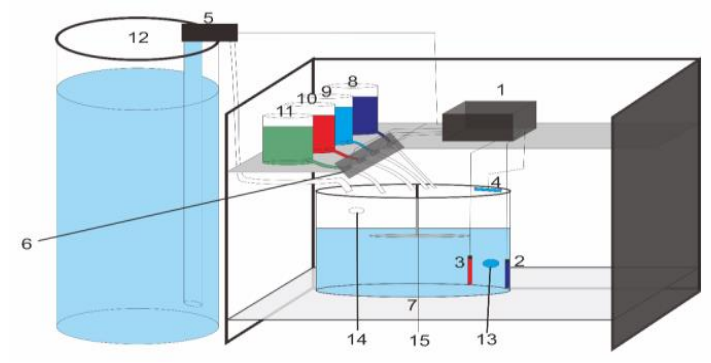

Gambar 3.2 Desain Alat

Keterangan :

1. Kotak pengontrol.

2. Ph meter.

3. TDS meter.

4. Sensor ultrasonik.

5. Pompa air dc.

6. Waterflow swicth / selenoid valve

7. Bak penampungan air hidroponik.

8. Cairan $\mathrm{pH}$ up

9. Cairan $\mathrm{pH}$ down

10. Cairan nutrisi abmix a

11. Cairan nutrisi abmix b

12. Tandon air utama

13. Lubang output air ke hidroponik

14. Lubang input air dari hidroponik

15. Dinamo pengaduk (pompa air)

\subsection{Flowchart}

Berikut flowchart mengenai alat pengontrol kadar ph dan nutrisi dalam hidroponik yang akan dibuat : 


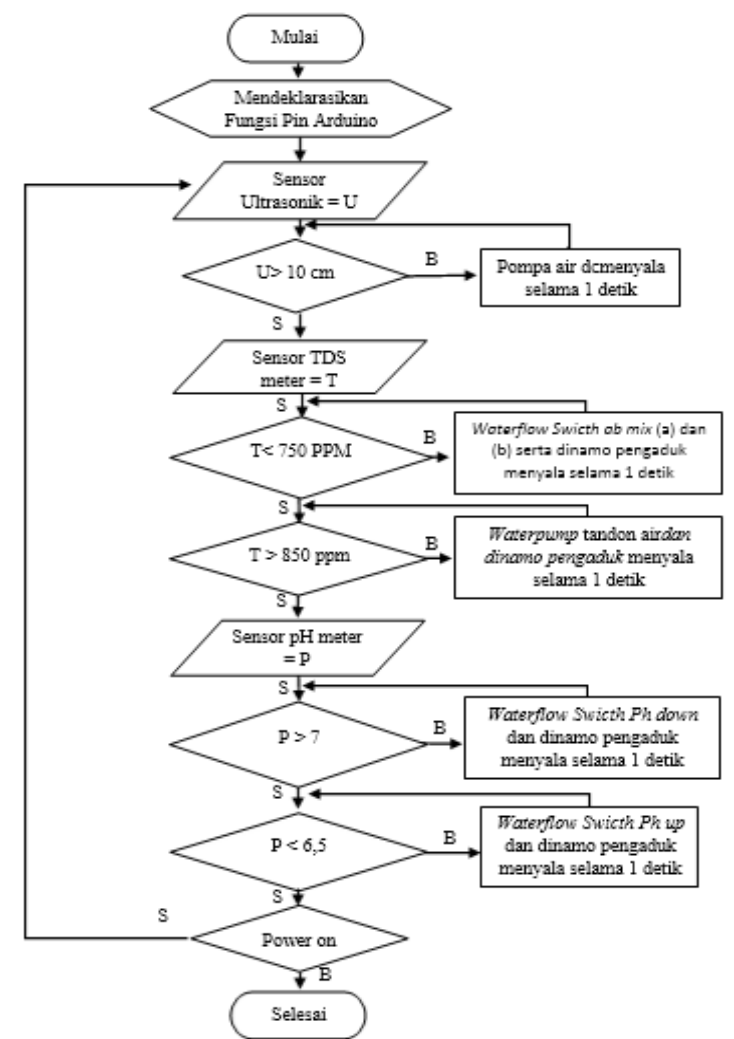

Gambar 3.3 Flowchart Alat Pengontrol Ph dan Nutrisi

Berikut penjelasan mengenai flowchart yang digunakan dalam alat pengontrol kadar ph dan nutrisi pada hidroponik:

1. Mendeklarasikan Fungsi Pin Arduino. Pin yang dideklarasikan hanya pin yang digunakan untuk pembuatan alat.

2. Menyederhanakan nama variabel sensor ultrasonik menjadi huruf U.

3. Menjalankan pengkondisian sensor ultrasonik U $>10 \mathrm{~cm}$. jika jarak sensor ultrasonik dengan air lebih dari $10 \mathrm{~cm}$ makan pompa air motor dc akan menyala 1 detik dan kembali ke rumus pengkondisian sensor ultrasonik selama pengkondisian masih benar, jika rumus pengkondisian salah maka akan melanjutkan ke langkah selanjutnya.

4. Menyederhanakan variabel sensor TDS meter dengan huruf $\mathrm{T}$.

5. Menjalankan pengkondisian sensor TDS meter dengan rumus $\mathrm{T}<750 \mathrm{ppm}$. Jika TDS meter kurang dari 750 ppm, maka waterflow swicth $a b$ mix (pupuk a dan pupuk b) dan dinamo pengaduk akan menyala 1 detik selama rumus pengkondisian masih benar. Jika rumus pengkondisian salah maka program akan melanjutkan ke langkah selanjutnya.

6. Menjalankan pengkondisian sensor TDS meter dengan rumus $\mathrm{T}>850 \mathrm{ppm}$. Jika TDS meter lebih dari $850 \mathrm{ppm}$, maka pompa air motor dcdan dinamo pengaduk akan menyala 1 detik selama rumus pengkondisian masih benar. Jika rumus pengkondisian salah maka program akan melanjutkan ke langkah selanjutnya.

7. Menyederhanakan variabel sensor ph meter menjadi huruf $P$.

8. Menjalankan pengkondisian sensor ph meter dengan rumus $P>7,5$. Jika ph meter lebih dari 7,5 maka waterflow swicth ph downdan dinamo pengaduk akan menyala 1 detik selama rumus pengkondisian masih benar. Jika rumus pengkondisian salah maka program akan melanjutkan ke langkah selanjutnya.

9. Menjalankan pengkondisian sensor ph meter dengan rumus $\mathrm{P}<6,5$. Jika ph meter kurang dari 6,5 maka waterflow swicth ph updan dinamo pengaduk akan menyala 1 detik selama rumus pengkondisian masih benar. Jika rumus pengkondisian salah maka program akan melanjutkan ke langkah selanjutnya.

10. Pengkondisian power, jika power menyala maka program akan kembali ke pengkondisian pertama dan program akan berjalan terus menerus sampai kondisi dimana power tidak menyala.

\section{HASIL DAN PEMBAHASAN}

Pada bab ini penulis akan menjelaskan tentang persiapan mengenai komponen-komponen yang digunakan, langkah-langkah yang dilakukan untuk menguji komponen, dan proses pembuatan alat dari awal sampai proses pengujian alat secara menyeluruh. Sebelum melakukan pengujian komponen, penulis terlebih dahulu mempelajari komponen tersebut untuk meminimalisir kesalahan dan data yang tidak valid.

\subsection{Tujuan Pengujian}

Pengujian berfungsi untuk mendapatkan suatu data penelitian yang berasal dari hasil analisis sesuai dengan kondisi sebenarnya mengenai Alat Pengontrol Kadar pH Air dan Nutrisi ABMIX Menggunakan Arduino pada Sistem Hidroponik Sayur Hijau, sehingga jika terdapat suatu kerusakan komponen pada alat maka dapat di perbaiki dengan mudah.

\subsection{Pengujian Produk}

Uji coba produk bertujuan untuk mengetahui bagaimana kinerja sebuah produk hasil dari penelitian. Pengujian produk terdiri dari 2 tahap, yaitu pengujian komponen dan pengujianalat.

\subsubsection{Perakitan komponen}

a. Kotak pengontrol

Pengontrolan pada alat ini menggunakan 2 buah mikrokontroller arduino dengan fungsi arduino 1 sebagai pengontrol ketinggian air dan kepekatan nutrisi, sedangkan arduino 2 berfungsi sebagai pengontrol kadar $\mathrm{pH}$ air pada bak penampungan air hidroponik.

Arduino Uno 1 terhubung ke 4 komponen pendukung yaitu modul sensor TDS meter, rellay 4 channel, modul sensor sensor ultrasonik, dan lcd 
16x2 i2c. Pada rangkaian rellay, arduino hanya terkoneksi pada vcc, gnd, input 1 dan input 2, karena input 3 dan input 4 digunakan oleh Arduino Uno 2 untuk mengontrol pompa air $p H U p$ dan $p H$ Down.

Pin A0 pada arduino yang terhubung ke modul TDS meter AO berfungsi untuk membaca tingkat kepekatan air dengan bantuan sensor TDS meter. Pin 4 pada arduino yang terhubung ke rellay input 1 berfungsi untuk menyalakan atau mematikan pompa air pada tandon air luar supaya air pada bak penampungan tidak kekurangan atau kelebihan air. Pin 5 pada arduino yang terhubung ke rellay input 2 berfungsi untuk mematikan dan menyalakan 2 pompa air dari tabung nutrisi ABMIX A dan B sehingga air di dalam bak penampungan tidak mengalami kekurangan nutrisi. Pin 9 dan pin 10 pada arduino terkoneksi ke sensor ultrasonik echo dan trigger yang berfungsi untuk melakukan pembacaan ketinggian air pada bak penampungan air, sehingga nilainya dapat digunakan untuk pengkondisian rellay. Pin A4 dan A5 pada arduino yang terhubung ke lcd $16 \times 2$ i2c berfungsi sebagai pin data untuk menampilkan hasil inputan sensor ke lcd $16 \times 2$ i $2 \mathrm{c}$.

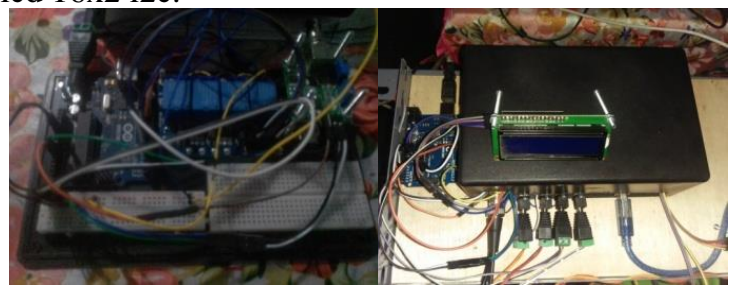

Gambar 3.1 Kotak Pengontrol

Arduino Uno 2 terhubung ke 3 komponen pendukung yaitu sensor $\mathrm{pH}$ meter, ellay 4 chanel, dan lcd 16x2 i2c. Pin A1 pada arduino yang terhubung ke sensor $\mathrm{pH}$ meter berfungsi sebagai pin input dari sensor $\mathrm{pH}$ meter yang nilainya digunakan untuk pengkondisian rellay untuk mengontrol pompa air pada tabung $p H U p$ dan $p H$ Down. Pin 6 pada arduino yang terhubung ke rellay input 3 yang berfungsi untuk menyalakan atau mematikan pompa air pada tabung $p H U p$. Pin 7 pada arduino yang terhubung pada rellay input 4 berfungsi untuk mematikan atau menyalakan pompa air pada tabung pH Down. Pin A4 dan A5 pada arduino yang terhubung ke lcd $16 \times 2$ i2c berfungsi sebagai pin data untuk menampilkan hasil inputan sensor ke lcd 16x2 i2c. Kotak pengontrol dilengkapi dengan jack $D C$ sebagai konektor, sehingga tidak harus membongkar kotak pengontrol untuk melakukan instalasi rangkaian alat.

b. Instalasi sensor

Sensor pH meter dan TDS meter diletakkan pada dasar bak penampungan air hidroponik namun tidak menempel pada dinding bak penampungan supaya sensor dapat melakukan pembacaan data secara maksimal.

Sensor $\mathrm{pH}$ meter harus dihubungkan terlebih dahulu ke modul $\mathrm{pH}$ meter agar sensor dapat dikontrol dan diakses oleh Microcontroller Arduino Uno, setelah itu modul $\mathrm{pH}$ meter dihubungkan ke pin Arduino Uno . pin yang digunakan untuk $\mathrm{pH}$ meter yaitu pin A1, pin 5v, dan pin Gnd.

Sensor TDS meter terlebih dahulu dihubungkan ke modul TDS meter menggunakan kabel bawaan dari sensor TDS meter. Setelah terhubung ke modul TDS meter, maka modul tersebut dihubungkan ke pin arduino supaya sensor dapat dikontrol oleh Microcontroller Arduino Uno. Pin yang digunakan untuk mengontrol sensor TDS meter yaitu pin A0, pin $5 \mathrm{v}$, dan pin Gnd.

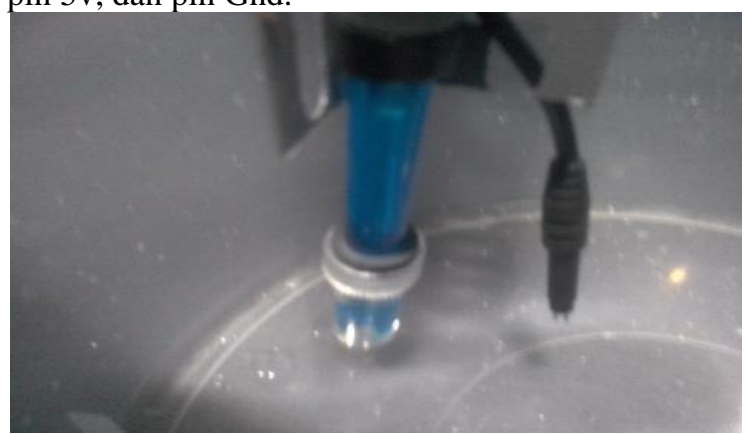

Gambar 3.2 Penempatan Sensor pH Meter dan TDS Meter

Sensor $\mathrm{pH}$ meter dan sensor TDS meter ditempatkan pada dasar bak penampungan air namun tidak boleh menempel pada dinding atau dasar bak supaya dapat melakukan pembacaan kondisi secara baik.

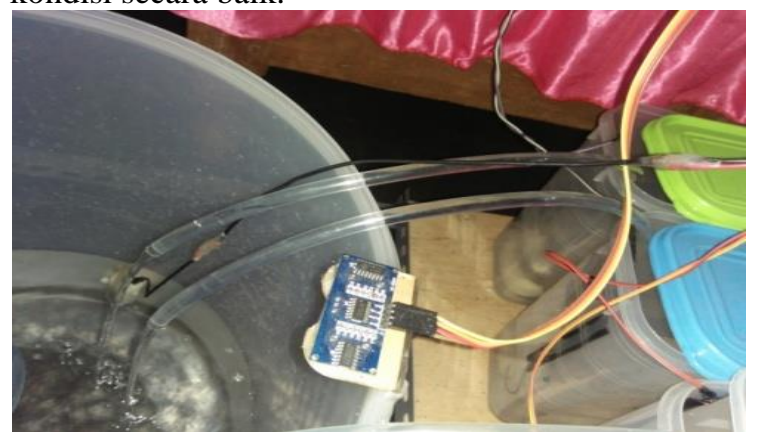

Gambar 3.3 Penempatan Sensor Ultrasonik

Sensor ultrasonik diletakkan di atas bak penampungan air untuk melakukan pembacaan tinggi air yang terdapat di dalam bak penampungan. Pemasangan sensor dilakukan dengan cara menempatkan sensor ultrasonik pada braked sensor ultrasonik setelah itu sensor direkatkan pada braked menggunakan lem bakar. Sensor ultrasonik yang telah direkatkan pada braked, selanjutnya braked direkatkan pada besi yang berada diatas bak penampungan air menggunakan baut bawaan dari braked.

\subsubsection{Pemrograman Alat}

Pemrograman alat berfungsi untuk memberikan perintah kepada mikrokontroller arduino supaya 
dapat mengontrol komponen komponen yang digunakan sehingga semua komponen dapat berjalan dengan baik sesuai dengan perintah yang telah dibuat.

a. Pemrograman Arduino Uno 1

\#include <EEPROM.h>

\#include "GravityTDS.h"

\#include <Wire.h>

\#include <LiquidCrystal_I2C.h>

\#define TdsSensorPin A0

GravityTDS gravityTds;

Float temperature $=25$;

int trig $=9$;

int echo $=10$;

int en $1=3$;

int en $2=2$;

int outair $=4$

int outnutrisi $=5$;

int maks $=200$;

int minim $=00$;

long duration, distance;

float tds Value $=0$

LiquidCrystal_I2C lcd(0x27, 16, 2);

Kode program diatas yaitu deklarasi Library dan deklarasi variabel yang digunakan untuk pemrograman alat pada Arduino Uno 1. Library yang digunakan untuk pemrograman pada arduino 1 yaitu Library TDS meter dan Library lcd $16 \times 2$ i2c.

void $\operatorname{setup}()\{$

Serial.begin(9600);

pinMode(trig, OUTPUT);

pinMode(echo, INPUT);

pinMode(en1, OUTPUT);

pinMode(en2, OUTPUT);

digitalWrite(en1,HIGH);

$\operatorname{lcd} \cdot \operatorname{begin}()$;

pinMode(outnutrisi, OUTPUT); pinMode(outair, OUTPUT);

gravityTds.setPin(TdsSensorPin);

gravityTds.setAref(5.0);

gravityTds.setAdcRange(1024);

gravityTds.begin();

ph.begin();

Kode program Void Setup berisi tentang pendeklarasian fungsi pada setiap variabel yang digunakan. Serial begin berfungsi untuk mengaktifkan serial monitor dari software Arduino $I D E$. pinMode dalam perintah tersebut berfungsi untuk mendeklarasikan pin tersebut menjadi pin output atau pin input.didalam Void setup ini juga terdapat inisialisasi program yang digunakan secara tetap dan dibaca waktu saat pertama kali program dijalankan dan tidak diulang.

void $\operatorname{loop}()\{$

/*ultrasonik*/

digitalWrite(trig,LOW);

delayMicroseconds(2);

digitalWrite(trig,HIGH);

delayMicroseconds(10);

digitalWrite(trig,LOW);

duration=pulseIn(echo,HIGH);

distance $=35$-duration $/ 58.2$;

Serial.print(distance);

Serial.println("cm");

lcd.setCursor $(0,0)$;

lcd.print(distance);

lcd.println("cm");

delay (1000);

lcd.clear();

while $($ distance $<10)\{$

digitalWrite(outair,HIGH);

digitalWrite(outnutrisi,LOW);

digitalWrite(trig,LOW);

delayMicroseconds(2); digitalWrite(trig,HIGH);

delayMicroseconds(10); digitalWrite(trig,LOW);

duration=pulseIn (echo,HIGH);

distance $=35$-duration $/ 58.2$;

Serial.print(distance);

Serial.println("Cm");

lcd.setCursor(0,0); lcd.print(distance);

lcd.println("cm"); delay(1000);

lcd.clear();

\}

digitalWrite(outair,LOW);

digitalWrite(outnutrisi,LOW); \}

Alur dari kode program diatas yaitu dimulai dari pemberian voltase untuk pin trigger untuk mengirimkan sinyal suara ultrasonikyang kemudian akan dipantulkan oleh air lalu akan kembali ke sensor ultrasonik melalui pin echo setelah itu akan diketahui berapa lama sinyal tersebut dikirimkan dari trigger menuju echo. Untuk mengetahui jarak antara air dengan sensor dapat diketahui menggunakan rumus distance $=$ duration/59.2. Untuk mengetahui tinggi air perlu merubah rumus untuk mengetahui tinggi air, karena tinggi bak $35 \mathrm{~cm}$, maka tinggi air pada bak dapat diketahui dengan rumus tinggi=35-distance. Hasil dari inputan sensor ultrasonik yang telah diproses arduino menjadi tinggi air akan diproses kembali untuk pengkondisian pompa air pada tandon air luar dengan rumus while (distance $<10)$. Dalam program diatas pengkondisian ultrasonik yaitu jika tinggi air kurang dari $10 \mathrm{~cm}$ maka pompa air pada tandon air luar akan menyala untuk mengisi air pada bak 
penampungan air hidroponik lalu akan mati jika air sudah dalam ketinggian $10 \mathrm{~cm}$ atau lebih. Jika air sudah sudah mencapai $10 \mathrm{~cm}$ maka arduino akan membaca program selanjutnya.

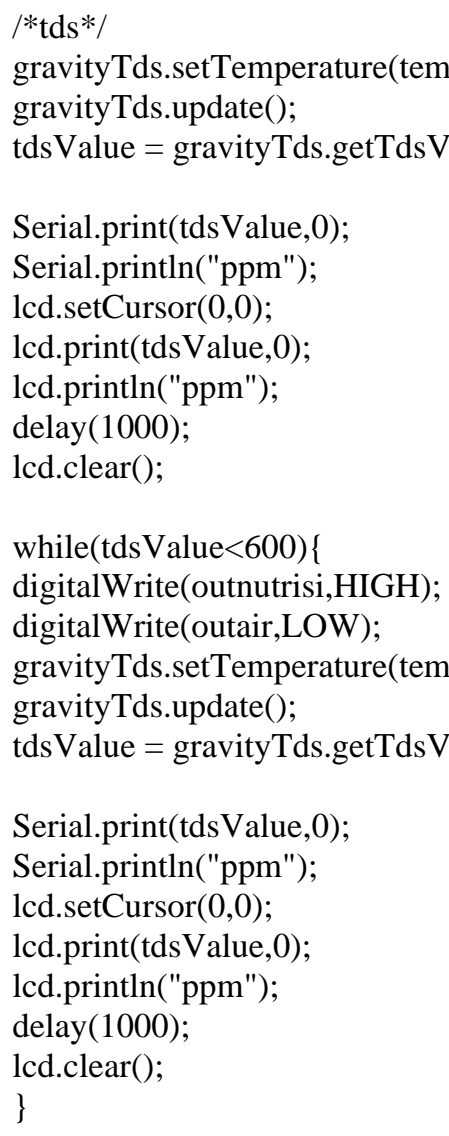

Alur kode program pada sensor TDS meter untuk nilai dibawah 600 PPM yaitu diawali dengan pembacaan dan pemrosesan nilai sensor. Setelah didapatkan nilai PPM pada air di bak penampungan maka lcd akan menampilkan hasil dari sensor dan arduino akan memproses pengkondisian while(tdsValue 6000 ), didalam loopong while ini pompa air nutrisi akan menyala sampai pengkondisian bernilai salah.
gravityTds.setTemperature(temperature); gravityTds.update(); //sample and calculate tdsValue = gravityTds.getTdsValue ()$; / /$ then get the value

Serial.print(tdsValue,0);

Serial.println("ppm");

lcd.setCursor $(0,0)$;

lcd.print(tdsValue, 0 );

lcd.println("ppm");

delay (1000);

lcd.clear();

while(tdsValue>1500)\{

digitalWrite(outnutrisi,LOW);

digitalWrite(outair,HIGH);

gravityTds.setTemperature(temperature);

gravityTds.update(); //sample and calculate

tdsValue $=$ gravityTds.getTdsValue

Serial.print(tdsValue,0);

Serial.println("ppm");

lcd.setCursor $(0,0)$;

lcd.print(tdsValue,0);

lcd.println("ppm");

delay (1000);

lcd.clear();

\}

Alur kode program pada sensor TDS meter untuk nilai diatas 1500 PPM yaitu diawali dengan pembacaan dan pemrosesan nilai sensor. Setelah didapatkan nilai PPM pada air di bak penampungan maka lcd akan menampilkan hasil dari sensor dan arduino akan memproses pengkondisian while(tdsValue >1500), didalam loopong while ini pompa air pada tandon air luar akan menyala sampai pengkondisian bernilai salah. Pembacaan program akan kembali lagi ke kode program yang pertama didalam fungsi void loop dan akan menyala terus menerus selama arduino teraliri oleh arus listrik.

b. Pemrograman Arduino Uno 2

Arduino Uno 2 berfungsi sebagai pengontrol kadar $\mathrm{pH}$ air dalam bak penampungan hidroponik. Berikut kode program yang digunakan dalam pembuatan alat ini.

\#include <Wire.h>

\#include <LiquidCrystal_I2C.h>

LiquidCrystal_I2C lcd(0x27, 16, 2);

const int analogInPin $=\mathrm{A} 1$; int sensorValue $=0$;

unsigned long int avgValue; float $b$;

int buf,temp; int en2=2;

int outphup=8; int outphdown=9;

Alur kode program diatas yaitu diawali dengan memasukkan library yang dibutuhkan dalam proses pemrograman pada arduino 2. Library yang digunakan yaitu liquidCrystal yang berfungsi untuk membantu pemrograman lcd $16 \mathrm{c} 2$ i2c. Setelah 
library dimasukkan selanjutnya memasukkan pin pin yang digunakan untuk menjalankan perintah.

Arduino Uno 2 menggunakan 4 pin sebagai pengontrol, yaitu pin 2 berfungsi untuk mengontrol kecepatan pompa air, pin 8 berfungsi untuk mengontrol pompa air $p H U p$ menyala atau mati, pin 9 berfungsi untuk mengontrol pompa air $p H$ Down menyala atau mati, dan pin A1 yang berfungsi untuk menerima hasil iputan dari sensor $\mathrm{pH}$ meter.

\section{void $\operatorname{setup}()\{$}

Serial.begin(9600); pinMode(en2, OUTPUT);

pinMode(outphup, OUTPUT);

pinMode(outphdown, OUTPUT);

digitalWrite(en2,HIGH); lcd.begin(); \}

Kode program void setup pada Arduino Uno 2 berisi tendang deklarasi fungsi pin input dan outpu. Perintah serial.begin berfungsi untuk mengaktifkan serial monitor pada arduino, sedangkan perintah lcd.begin berfungsi untuk mengaktifkan lcd 16x2 i2c sehingga dapat menampilkan karakter yang diperintahkan oleh arduino.

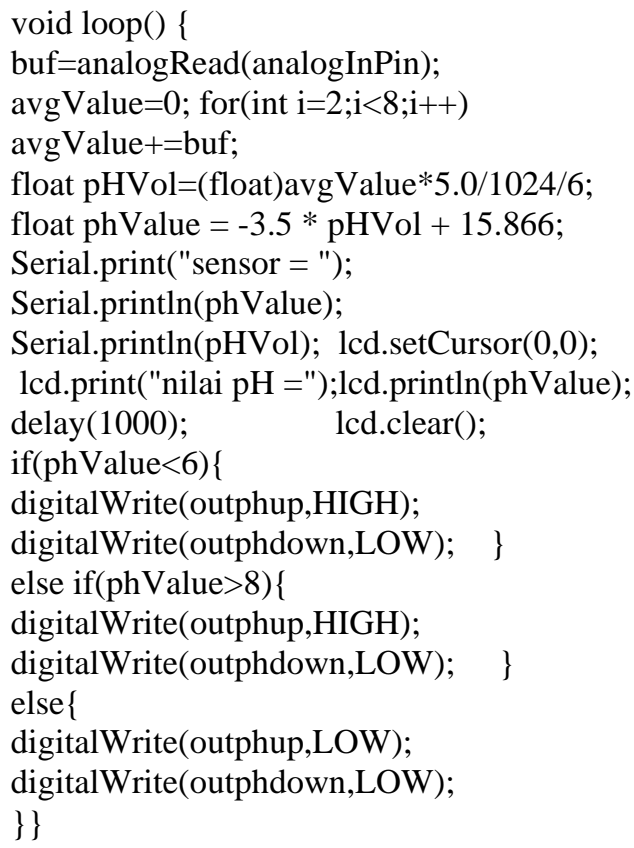

Alur Kode program void setup pada arduino uno 2 yaitu diawali dengan pembacaan nilai voltase pada sensor, lalu nilai voltase tersebut dimasukkan kedalam rumus untuk mengetahui nilai $\mathrm{pH}$ pada air. Setelah mendapatkan nilai $\mathrm{pH}$, maka arduino akan menjalankan perintah untuk menampilkan hasil sensor pada lcd dan nilai sensor digunakan untuk proses pengkondisian untuk menyalakan pompa air $p H \quad U p$ dan pompa air $p H$ Down. Jika nilai $\mathrm{pH}$ dibawah 6 maka pompa air $p H U p$ akan menyala sampai nilai $\mathrm{pH}$ berada di angka 6 atau lebih lalu pompa air akan berhenti, jika nilai $\mathrm{pH}$ diatas 8 maka pompa air $p H$ Down akan menyala untuk menurunkan kadar $\mathrm{pH}$ smpai $\mathrm{pH}$ di angka 8 lalu pompa air akan berhenti.

\subsubsection{Pengujian alat}

Pengujian alat dilakukan dengan cara menyalakan semua komponen yang sudah terakit menjadi satu alat, setelah itu alat akan membaca kondisi pada air di bak penampungan air hidroponik, lalu dari kondisi tersebut pompa air akan dikrontrol sesuai dengan kondisi air pada bak penampungan air hidroponik. Berikut tabel hasil pengujian alat hidroponik.

Tabel 3.1 Pengujian Alat Arduino Uno 1

\begin{tabular}{llcc}
\hline No. & Kondisi Air & $\begin{array}{c}\text { Pompa Air } \\
\text { Tandon }\end{array}$ & $\begin{array}{c}\text { Pompa Air } \\
\text { Nutrisi }\end{array}$ \\
\hline 1. & $8 \mathrm{~cm}$ & $\sqrt{ }$ & - \\
2. & $8 \mathrm{~cm}$ & $\sqrt{ }$ & \\
3. & $9 \mathrm{~cm}$ & $\sqrt{ }$ & \\
2. & $10 \mathrm{~cm}$ & - & - \\
3. & 166 PPM & - & $\sqrt{ }$ \\
4. & 255 PPM & & $\sqrt{ }$ \\
5. & 635 PPM & - & - \\
\hline
\end{tabular}

Alur dari pengujian alat Arduino Uno 1 yaitu sesuai dengan kode program yang telah dibuat sebelumnya yaitu pengecekkan ketinggan air terlebih dahulu, pada pengecekkan ketinggian air. Pada pembacaan sensor pertama kondisi air berada di ketinggian $8 \mathrm{~cm}$ dan pompa air tandon menyala sampai pembacaan nilai sensor mencapai $9 \mathrm{~cm}$. Pompa air tandon berhenti menyala saat tinggi air berada di angka $10 \mathrm{~cm}$. Setelah pengkondisian tinggi air selesai, selanjutnya yaitu pengecekkan kadar kepekatan nutrisi dengan menggunakan sensor TDS meter. Pada pengujian tingkat kepekatan air, nilai sensor berada di angka 166 PPM sehingga pompa air pada tabung nutrisi menyala sampai nilai sensor di angka 600 PPM. Pembacaan nilai kepekatan air berada di angka 635 PPM membuat pompa air nutrisi terhenti dan melanjutkan program looping pada Arduino Uno 1.

Tabel 3.2 Pengujian Arduino Uno 2

\begin{tabular}{llcc}
\hline No. & Kondisi Air & $\begin{array}{c}\text { Pompa Air } \\
\text { pH Up }\end{array}$ & $\begin{array}{c}\text { Pompa Air pH } \\
\text { Down }\end{array}$ \\
\hline 1. & pH 13.21 & - & $\sqrt{ }$ \\
3. & pH 7.42 & - & - \\
4. & pH 6.8 & - & - \\
5. & pH 7.14 & - & - \\
6. & pH 6.00 & - & - \\
7. & pH 5.89 & $\sqrt{ }$ & - \\
8. & pH 6.00 & - & - \\
9. & pH 7.14 & - & - \\
10 & pH 6.8 & - & - \\
\hline
\end{tabular}

Alur dari pengujian alat Arduino Uno 2 yaitu terlebih dahulu sensor melakukan pembacaan kondisi pada air. Pada pengujian pertama nilai sensor berada di angka $\mathrm{pH} 13.21$, dengan nilai $\mathrm{pH}$ tersebut pompa air $\mathrm{pH}$ Down menyala selama $\mathrm{pH}$ air 
berada di bawah angka 8 . Setelah pompa air $\mathrm{pH}$ Down menyala nilai sensor berada di angka 7.42 sehingga pompa air $\mathrm{pH} \mathrm{Up}$ dan $\mathrm{pH}$ down mati. Percobaan ke 7 nilai $\mathrm{pH}$ berada di angka 5.89 yang sehingga pompa air $\mathrm{pH}$ down menyala sampai berada di $\mathrm{pH}$ netral.

\section{KESIMPULAN}

Berdasarkan penelitian yang telah dilakukan mengenail Alat Pengontrol Kadar Ph Air Dan Nutrisi Ab Mix Menggunakan Arduino Pada Sistem Hidroponik Sayur Hijau peneliti mengambil kesimpulan antara lain :

1. Ketika nilai tinggi air berada di bawah angka 10 , pompa air tandon menyala dan mati ketika sudah mencapai angka $10 \mathrm{~cm}$.

2. Pembacaan sensor TDS meter dilakukan saat tinggi air sudah mencapai $10 \mathrm{~cm}$.

3. Pompa air pada tabung nutrisi menyala saat nilai sensor TDS meter berada di angka 166 PPM dan berhenti saat nilai PPM berada di angka 635

4. Pompa air $\mathrm{pH}$ Down menyala saat $\mathrm{pH}$ meter mendeteksi kadar $\mathrm{pH}$ di angka 13.21

Sensor $\mathrm{pH}$ meter dan TDS meter pada Alat Pengontrol Kadar Ph Air Dan Nutrisi Ab Mix Menggunakan Arduino Pada Sistem Hidroponik Sayur Hijau melakukan pembacaan nilai sensor dengan hasil fluktuatif ketika air dalam bak penampungan mengalami pergerakkan. Alat ini perlu pengontrollan pengaduk dan jeda waktu sebelum melakukan pembacaan nilai sensor berikutnya.

\section{PUSTAKA}

Harum Cahyani, Harmadi, Wildian. 2016. Pengembangan Alat Ukur Total Dissolved Solid (Tds) Berbasis Mikrokontroler Dengan Beberapa Variasi Bentuk Sensor Konduktivitas. Jurnal Fisika Unand Vol. 5, No. 4.

Kustanti, Ika. 2014. Pengendalian kadar keasaman $(\mathrm{pH})$ pada sistem hidroponik stroberry menggunakan kontroller PPID berbasis arduino uno . PPSSI - Jurnal Teknik Elektro, 8(1), 57-65.

Sugiyono. 2011. Metode Penelitian Kuantitatif, Kualitatif dan R\&D. Bandung: Afabeta

Sugiyono. 2015. Metode Penelitian Kombinasi (Mix Methods). Bandung: Alfabeta.

Sulaiman, Arif .2012. ARDUINO : Mikrocontroller bagi Pemula hingga Mahir.

Sutiyoso Y. 2004. Hidroponik Ala Yos. Jakarta (ID) : Penebar Swadaya.

(Online), (NETTRAIN@ubvm.cc.buffalo.edu, diakses 22 November 1995). 